11. Формы повелительного наклонения часто употребляются в значении желательного наклонения. Примеры: Халиков ағайға әйтегез, иртәгә балаһын баксаға ебәрмәһен, урын юк! (Н.Мусин). Ана кыззың бер туған ағаһы әйтhен (М.Карим). Ирзең ике күзе ут булһын, әйткән һүзе мут булһын! (М.Карим). Гөлғәйшә Үзе яуап бирһен (М.Карим). Килһен дә керһен (А.Аминев). Булдыра алар икән, тотһон да үззәре язһын (А.Аминев). Ашығыз тәмле булһын, король! (И.Абдуллин). Бөтһөн һуғыш! Йәшәһен ирекле Италия! (И.Абдуллин).

Таким образом, система средств передачи различных оттенков желательной модальности в башкирском языке сложна и многообразна.

1. Грамматика современного башкирского литературного языка / Отв. редактор А.А.Юлдашев. М.: Наука, 1981. 496 с.

2. Дмитриев Н.К. Грамматика башкирского языка. М.-Л., 1948. 275 с.

3. Зайнуллин М.В. Система лексических и лексико-грамматических средств выражения модальных значений в современном башкирском языке. Уфа: БДУ, 1981. 82 с.

4. Зайнуллин М.В. Модальность как функционально-семантическая категория: На материале башкирского языка. Саратов: Изд-во Саратовского университета, 1986. 123 с.

5. Зайнуллин М.В. О сущности и границах категории модальности в башкирском языке. Уфа: БГУ, 2000. 293 с.; Уфа: БГУ, 2013. 380 с.

6. Зәйнуллин М.В. Хәзुерге башкорт телендә модаллек категорияһы. Өфө, 1975. 165 бит.

7. Ишбулатов Н.Х. Хәзुерге башкорт теле. Һүз төркөмдәренең бүленеше. Өфө, 1962. 126 бит.

8. Юлдашев А.А. Система словообразования и спряжения глагола в башкирском языке. - М.: Наука, 1958. $195 \mathrm{c}$.

\title{
Коновалова М.В.
}

\section{Имена и образы в цикле С. А. Есенина «Персидские мотивы»}

Филиал Брянского государственного университета в г. Новозыбкове (Россия, Новозыбков)

doi: $10.18411 / \mathrm{j}-07-2021-168$

\section{Аннотация}

В публикации рассматриваются имена собственные, употребляющиеся в цикле «Персидские мотивы» С.А. Есенина (1895-1925). Имена художественного текста (или поэтонимы) классифицированы по специфике денотативного значения, рассматривается их семантика, роль в стихотворениях, частотность использования, соотношение ономастических разрядов в каждом стихотворении.

Ключевые слова: С.А. Есенин, цикл «Персидские мотивы», поэтонимы, образы, лирика.

\section{Abstract}

The publication discusses proper names used in the cycle "Persian motifs" by S. A. Yesenin (1895-1925). The names of the literary text (or poetonyms) are classified according to the specifics of the denotative meaning, their semantics, their role in poems, the frequency of use, the ratio of onomastic categories in each poem are considered.

Keywords: S. A. Yesenin, the cycle "Persian motifs", poetonyms, images, lyrics.

Актуальность темы статьи продиктована недостаточностью научных исследований, рассматривающих поэтонимы в цикле «Персидские мотивы» С.А. Есенина. Онимы занимают особое место и играют важную роль в его лирике. Онив своём семантическом поле содержат информацию о человеке и окружающей его среде и выступают, таким образом, средством выражения авторской картины мира. 
Цикл «Персидские мотивы», написанный в 1924-1925 гг. во время поездки Есенина на Кавказ, занимает особое место в творчестве поэта. Есенин всем сердцем желал посетить Персию, но по определённым причинам у него этого не получилось. В «Персидских мотивах» выразилось тяготение поэта к Востоку. Состоит циклиз 15 стихотворений. Значительную роль в них играютпоэтонимы: помимо номинативной функции, они выполняют характеризующую, идеологическую, стилистическую функции.

Количество употребления поэтонимов в «Персидских мотвах» отражено в Таблице 1.

Таблий 1

Количество поэтонимов в стихотворениях цุикла «Персидские мотивыл» С.А. Есенина

\begin{tabular}{|c|c|c|}
\hline № п/п & Название стихотворения, год написания & $\begin{array}{l}\text { Количество } \\
\text { поэтонимов }\end{array}$ \\
\hline 1 & «Улеглась моя былая рана...», 1924 & 3 \\
\hline 2 & «Я спросил сегодня у менялы...», 1924 & 4 \\
\hline 3 & «Шаганэ ты моя, Шаганэ!..», 1925 & 9 \\
\hline 4 & «Ты сказала, что Саади...», 1925 & 4 \\
\hline 5 & «Никогда я не был на Босфоре...», 1925 & 4 \\
\hline 6 & «Свет вечерний шафранного края...»»,1925 & 4 \\
\hline 7 & «Воздух прозрачный и синий...», 1925 & 4 \\
\hline 8 & «Золото холодное луны...»», 1925 & 3 \\
\hline 9 & «В Хороссане есть такие двери....», 1925 & 5 \\
\hline 10 & «Голубая родина Фирдуси...», 1925 & 6 \\
\hline 11 & «Быть поэтом - это значит то же...», 1925 & 2 \\
\hline 12 & «Руки милой - пара лебедей...», 1925 & 2 \\
\hline 13 & «Отчего лунатак светит тускло...», 1925 & 4 \\
\hline 14 & «Глупое сердце, не бейся...», 1925 & 1 \\
\hline 15 & «Голубая да весёлая страна...», 1925 & 2 \\
\hline \multicolumn{2}{|r|}{ Всего употреблений: } & 57 \\
\hline
\end{tabular}

Как видно, стихотворение «Шаганэ ты моя, Шаганэ...»является самым насыщенным поэтонимами, а в стихотворении «Глупое сердце, не бейся...» присутствует лишь 1 поэтоним Лала.

На основе таблицы, представленной в работе С.М. Пронченко «Имена собственные в поэтической системе графа А.К. Толстого: парадигматический и синтагматический аспекты» [5, с. 26-27], был составлен упрощённый вариант Таблицы 2.

Таблийа 2

Частотность употребления ономастических разрядов вцикле «Персидские мотивы С.А. Есенина

\begin{tabular}{|c|c|c|c|}
\hline $\begin{array}{c}\text { № } \\
\text { П. П. }\end{array}$ & Ономастический разряд & Выявлено & Частотность употребления \\
\hline 1 & Антропоэтонимы & 9 & 35 \\
\hline 2 & $\begin{array}{l}\text { Топопоэтонимы, в том числе: } \\
\text { астиопоэтонимы } \\
\text { пелагопоэтонимы } \\
\text { потамопоэтонимы } \\
\text { лимнопоэтонимы } \\
\text { хоропоэтонимы }\end{array}$ & $\begin{array}{l}9 \\
3 \\
1 \\
1 \\
1 \\
1 \\
3\end{array}$ & $\begin{array}{c}22 \\
7 \\
2 \\
1 \\
1 \\
11\end{array}$ \\
\hline 3 & Агиопоэтонимы & 1 & 1 \\
\hline 4 & Библиопоэтонимы & 1 & 1 \\
\hline \multicolumn{2}{|c|}{ Всего: } & 20 & 57 \\
\hline
\end{tabular}


Таким образом, в ходе анализа выявлено 20 поэтонимов. Самыми частоупотребляемыми разрядами являются антропоэтонимы и топопоэтонимы.

Для полноты картины функционирования поэтонимов в есенинском цикле был проведён типологический анализ, связанный со спецификой денотативного значения. Содержание ономастических разрядов соотносилось со «Словарем русской ономастической терминологии» Н. В. Подольской [4].

Антропоэтонимы - это имена людей, их отчества и фамилии. В цикле употреблены 3 единицы: Шаганэ, Лала, Гелия[1, с. 28], а также 5 имён, обозначающих мужские образы: Магомет, Фирдуси, Саади, Хаям, Гассан.

Ко второй группе относятся топопоэтонимы, обозначающие географические объекты. В ходе сплошной выборки были выявлены 9 топопоэтонимов: Тегеран, Шираз, Багдад, Босфор, Евфрат, Ван, Персия, Хорасан, Русь (Россия), которые были распределены на 5 подклассов, как это предлагается в работе С. М. Пронченко [7, с. 141]:

— астиопоэтонимы (названия городов): Тегеран, Шираз, Багдад;

— пелагопоэтонимы (названия морей и заливов): Босфор;

— потамопоэтонимы (названия рек, каналов): Евфрат;

— лимнопоэтонимы (названия озёр, прудов): Ван [8, с. 192];

- административные хоропоэтонимы (названия государств, республик, краёв, районов): Персия, Хорасан, Русь (Россия).

Третья группа - библиопоэтонимы (названия текстов, книг), являющиеся разновидностью идеопоэтонимов - явлений духовной культуры. В стихотворении «Быть поэтом - это значит то же...» цикла выявлен 1 библиопоэтоним Коран:

Магомет перехитрил в Коране,

Запрещая крепкие напитки [2, с. 292].

Ещё в раннем творчестве С. А. Есенина среди агиопоэтонимов Господь, Бог преобладал последний. Со временем он начал употребляться реже. Именно этот агиопоэтоним встретился и в позднем периоде творчества писателя, в «Персидских мотивах». В стихотворении «Ты сказала, что Саади...»он употреблён 1 раз:

Подожди ты, Бога ради,

Обучусь когда нибудь! [2, с. 279]

Сформированная нами картотека имён из цикла позволяет констатировать, что по морфологическому составу поэтонимы являются простыми. Как и И. А. Бунин, Есенин избирает имена экзотические, «чуждые слуху» русского народа [6, с. 266]. Значительная часть таких единиц употребляется с целью раскрытия темы его цикла темы Востока.

Художественное пространство стихотворений С.А. Есенина изображается точечно, создаётся с участием разнообразных подклассов топопоэтонимов. Этот разряд имен участвует в создании картин природы. В целом ономастикон цикла «пространственно ориентирован» [3, с. 292]. В цикле нет отсылок на другие художественные тексты, но присутствует один интертекстуальный поэтоним библиопоэтоним Коран.

Исходя из проведённого анализа, отметим, что в цикле «Персидские мотивы» наблюдается диалог культур. Вначале своего творческого пути поэт в своих произведениях художественно восссоздавал Русь и только в последнем периоде творчества - Восток. Употребление в есенинском цикле ономастической лексики выражает авторский замысел. Посредством поэтонимов создаётся восточный колорит.Таким образом, поэтонимы очень важны: они помогают создавать образы, 
передавать авторские предпочтения, связанныес культурой Востока, раскрывать оригинальную творческую личность великого русского поэта.

$$
* * *
$$

1. Гунтарева Е. Е. Имена собственые в цикле «Персидские мотивы» С. А. Есенина // Вестник Московского государственного областного университета. Серия: Русская филология. $-2016 .-$ № 4. - C. 27-31.

2. Есенин С.А. Собрание сочинений: в 6 т. Т. 1: Стихотворения. - М.: Художественная литература, 1977. $-431 \mathrm{c}$.

3. Никулкина О. Г. Имена собственные в стихотворениях Б. Л. Пастернака (К 130-летию со дня рождения писателя) // Балтийский гуманитарный журнал. - 2020. - Т. 9. - № 2 (31). - С. 289-293.

4. Подольская Н. В. Словарь русской ономастической терминологии. М.: Наука, 1978. 199 с.

5. Пронченко С. М. Имена собственные в поэтической системе графа А. К. Толстого: парадигматический и синтагматический аспекты // Rhema. Рема. -2018. -№ 2. -C. 16-38.

6. Пронченко С. М. Имена собственные в стихотворениях И. А. Бунина: системный подход (К 145летию со дня рождения писателя) // Вестник Брянского государственного университета. -2015 . -№ 2. -C. 260-267.

7. Пронченко С. М. Поэтонимы в художественной системе исторического романа графа А. К. Толстого «Князь Серебряный» // Новый филологический вестник. -2021. -№ 1. -C. 138-147. -DOI: 10.24411/2072-9316-2021-00011.

8. Советский энциклопедический словарь / А. М. Прохоров, В. Г. Панов, А. А. Гусев, И. Л. Кнунянц [и др.]. - 4-е изд. - М.: Советская энциклопедия, 1988. - 1600 с.

\section{Корчалова Т.В., Осадчая Т.Ю. \\ Реализация медиастилистики в англоязычном интернет-пространстве (на материале текстов из социальных сетей)}

Гуманитарно-педагогическая академия (филиал) ФГАОУ ВО «Крымский федеральный университет имени В.И. Вернадского»

(Россия, Ялта)

doi: $10.18411 / \mathrm{j}-07-2021-169$

\section{Аннотация}

Данная статья посвящена медиастилистике, описано происхождение термина, современные проблемы и области данной отрасли стилистики. Целью статьи является рассмотрение стилистических приёмов, используемых для реализации авторских интенций в современном медиадискурсе. Практическая часть представлена рассмотрением некоторых стилистических средств реализации медиастилистики в англоязычном интернет-пространстве. В ходе исследования были проанализированы медиатексты, представленные на английском языке в социальных сетях Инстаграм и Фейсбук. В работе описаны и представлены примеры графических, лексических и синтаксических стилистических средств. Анализ приведённых примеров показывает, что медиастиль в рассмотренной области медиа характеризуется упрощением грамматических и синтаксических конструкций и форм слов, частым использованием графических стилистических приёмов, намеренным искажением слов. Для медиастиля современных социальных сетей характерно размывание грани между устной и письменной речью.

Ключевые слова: медиастилистика, медиатекст, медиадискурс, стилистические средства, социальная сеть.

\section{Abstract}

This article is focused on the media stylistics, it describes the origin of the term, current issues and areas of this new branch of stylistics. The purpose of the article is to analyze stylistic devices used to realize author's intentions in the contemporary media discourse. The practical part presents some stylistic means frequently used in English- 